\title{
Statistical Optimization of Biohydrogen Production from Palm Oil Mill Effluent by Natural Microflora
}

\author{
Zatilfarihiah Rasdi, Nor Aini Abdul Rahman*, Suraini Abd-Aziz, Phang Lai-Yee, Mohd Zulkhairi \\ Mohd Yusoff, Chong Mei-Ling and Mohd Ali Hassan
}

\author{
Department of Bioprocess Technology, Faculty of Biotechnology and Biomolecular Sciences, University Putra \\ Malaysia, 43400 UPM, Serdang, Selangor, Malaysia
}

\begin{abstract}
In this study, palm oil mill effluent (POME) was used as the substrate for biohydrogen production. Heat-treated POME sludge acclimated with POME incubated at $37^{\circ} \mathrm{C}$ for 24 hours was used as seed culture. Preliminary screening on the effects of inocula sizes, heat treatment, substrate concentration and $\mathrm{pH}$ of incubation by using a factorial design (FD) were conducted under mesophilic condition $\left(37^{\circ} \mathrm{C}\right)$ using a serum vial $(160 \mathrm{~mL})$. The experimental results from two-level FD showed that $\mathrm{pH}$ and Chemical Oxygen Demand (COD) of POME significantly affected biohydrogen production. Optimizations of the specific hydrogen production $\left(\mathrm{P}_{\mathrm{s}}\right)$ and the hydrogen production rate $\left(\mathrm{R}_{\mathrm{m}}\right)$ were achieved by using a central composite design (CCD). The maximum $\mathrm{P}_{\mathrm{s}}$ of $272 \mathrm{~mL} \mathrm{H}_{2} / \mathrm{g}$ carbohydrate was obtained under optimum conditions of pH 5.75 and substrate concentration of $80 \mathrm{~g} / \mathrm{L}$. The maximum $\mathrm{R}_{\mathrm{m}}$ of $98 \mathrm{~mL} \mathrm{H}_{2} / \mathrm{h}$ was calculated under the optimum conditions of pH 5.98 and substrate concentration of $80 \mathrm{~g} / \mathrm{L}$. The optimized conditions obtained were subjected to a confirma-

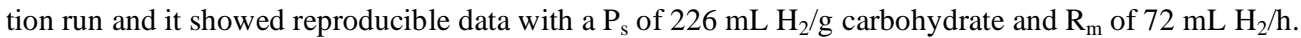

Keywords: Palm oil mill effluent, biohydrogen, central composite design.

\section{INTRODUCTION}

The production of palm oil as one of the major edible oils consumed in the world has increased tremendously in the last decade and is led by Malaysia, Indonesia and Thailand. However, during the milling process, a huge volume of palm oil mill effluent (POME) is being produced. Due to its characteristic of having a high organic content, the treatment and disposal of this waste is an economic burden on the palm oil industry. Thus, creating a marketable product from this waste would reduce the treatment cost. Recovery of energy from waste might reduce the cost of wastewater treatment, and contribute to reducing our dependence on fossil fuel. Hydrogen and energy production could mitigate these waste treatment problems [1].

Recently the feasibility of applying anaerobic fermentation of organic waste to produce hydrogen had been demonstrated by various laboratories [2-4]. Anaerobic systems have great potential to treat POME because of its highly organic content characteristic. These systems do not require high energy for aeration, thus allowing the recovery of energy in the form of biogas [5].

Biohydrogen is a promising clean fuel ultimately derived from renewable energy sources and it is environmentalfriendly. During the combustion of hydrogen, water will be produced as the sole product. It is high in energy yield and it could be produced by low-energy intensive processes [6]. Biohydrogen production is a complex process which is greatly influenced by many factors. These factors include

*Address correspondence to this author at the Department of Bioprocess Technology, Faculty of Biotechnology \& Biomolecular Sciences, University Putra Malaysia 43400 UPM, Serdang, Selangor, Malaysia;

E-mail: nor_aini@biotech.upm.edu.my substrate specificity, substrate concentration, reactor configuration, hydraulic retention time (HRT), organic loading rate $(\mathrm{OLR}), \mathrm{pH}$, temperature, oxidation-reduction potential, and nutritional requirements [4].

The optimization of fermentation conditions, particularly nutritional and environmental parameters are of primary importance for bioprocess development [7]. Other than nutrient composition, substrate concentration was found to be one of the most important factors affecting biohydrogen production $[8,9,11]$. Chong et al. [10] also reported that hydrogen production was strongly inhibited by $\mathrm{pH}$ values as low as $\mathrm{pH} 5$. A natural source has been used to provide inocula which are being selected for spore farmers and to destroy methanogens [12]. There are many research reports on different pretreatments such as base-enrichment [13], acid treatment [14] and heat treatment [10]. However, the enrichment of inocula by heat treatment is most common.

Conventional techniques such as a one-factor-at-a-time method is time consuming and laborious to perform. Therefore, statistical optimization has been chosen to depict the interactions among different factors and also to efficiently deal with a large number of factors [15]. The main objective of this study was to optimize the parameters for hydrogen production by natural microflora by using the Response surface methodology (RSM) approach. The individual and the interactive effects of $\mathrm{pH}$, different temperatures of heat treatment, different inoculum sizes and substrate concentrations on biohydrogen production were investigated in this study.

\section{MATERIALS AND METHODS}

\section{Seed Sludge}

The POME sludge used in this study was obtained from the anaerobic digester for POME treatment at FELDA Sert- 
ing Hilir Palm Oil Mill, Negeri Sembilan, Malaysia. Prior to use, the seed sludge was first allowed to settle and heated to inactivate the methanogens.

\section{Substrate}

The POME was obtained from FELDA Serting Hilir Palm Oil Mill located at Serting, Negeri Sembilan, Malaysia. Fresh hot POME $\left(80-90^{\circ} \mathrm{C}\right)$ was collected and kept in a cold room at $4{ }^{\circ} \mathrm{C}$ to avoid its degradation. The POME was used within a week and fresh POME was collected again from the same mill to ensure that its characteristic was consistent.

\section{Biohydrogen Fermentation}

The POME sludge was acclimatized in POME and incubated anaerobically at $37{ }^{\circ} \mathrm{C}$ for $24 \mathrm{~h}$ before being used as inoculum. POME with COD ranging from 40 - $80 \mathrm{~g} / \mathrm{L}$ COD inoculated with 10 to $20 \%(\mathrm{v} / \mathrm{v})$ of inoculum was incubated for $24 \mathrm{~h}$ in serum bottles to produce hydrogen. All the experiments were carried out in a $160 \mathrm{~mL}$ serum bottle containing $100 \mathrm{~mL}$ POME (medium). These bottles were flushed with nitrogen gas to ensure anaerobic conditions throughout the experiments, and were capped tightly with rubber septum (butyl rubber) [16]. Then, the bottles were incubated at $37^{\circ} \mathrm{C}$. The total gas volume was measured at $3 \mathrm{~h}$ intervals by releasing the pressure in the bottles using the syringe and water displacement method. All the experiments were carried out in triplicates.

\section{Analytical Methods and Data Analysis}

The biogas content was analyzed using a gas chromatograph equipped with a thermal conductivity detector and the column was packed with Porapack Q (80/100 mesh). The temperatures of the injector and the column were kept at $100^{\circ} \mathrm{C}$ and $50^{\circ} \mathrm{C}$, respectively. Nitrogen was used as the carrier gas with a flow rate of $30 \mathrm{~mL} / \mathrm{min}$. The COD of the samples were measured according to the standard methods [17]. The carbohydrate content was measured according to the phenol-sulphuric method.

The modified Gompertz equation was used to model the kinetics of the hydrogen production and to determine the specific hydrogen production potential $\left(\mathrm{P}_{\mathrm{s}}\right)$. The cumulative hydrogen production in the experiments followed the modified Gompertz equation [9]:

$H=P \exp \left\{-\exp \left[\frac{R_{m} e}{P}(\lambda-t)+1\right]\right\}$

$H$ represents the cumulative volume of hydrogen produced $(\mathrm{ml}), P$ the hydrogen potential $(\mathrm{ml}), R_{m}$ the maximum production rate $(\mathrm{ml} / \mathrm{h}), e$ the $2.71828 \ldots$ and $\lambda$ the lag time (h). The values of $P, R_{m}$ and $\lambda$ for each batch were determined by best fitting the hydrogen production data for this equation using the Statsoft Statistica 6.0.

The hydrogen gas production was calculated from the serum bottle headspace measurements of gas composition and the total volume of biogas at each interval using the following equation:

$V_{H, i}=V_{H, i-1}+C_{H, i}\left(V_{G, i}-V_{G, i-1}\right)+V_{H}\left(C_{H, i}-C_{H, i-1}\right)$

$\mathrm{V}_{\mathrm{H}, \mathrm{i}}$ and $\mathrm{V}_{\mathrm{H}, \mathrm{i}-1}$ are cumulative hydrogen gas volume at the current (i) and previous (i-1) time intervals, $\mathrm{V}_{\mathrm{G}, \mathrm{i}}$ and $\mathrm{V}_{\mathrm{G}, \mathrm{i}-1}$ the total biogas volumes in the current and previous time intervals, $\mathrm{C}_{\mathrm{H}, \mathrm{i}}$ and $\mathrm{C}_{\mathrm{H}, \mathrm{i}-1}$ the fraction of hydrogen gas in the headspace of the bottle measured using gas chromatography in the current and previous intervals, and $\mathrm{V}_{\mathrm{H}}$ the total volume of headspace in the bottle [10].

\section{OPTIMIZATION PROCEDURE}

\section{a) Two-Level Factorial Design}

In a factorial design, the influence of all experimental variables, factors and interaction effects on the responses are investigated [18]. Four variables, which were expected to affect biohydrogen production were selected based on a previous study. The significant effects of these variables on biohydrogen production were tested using a 2-level factorial design. The variables in the design were listed in Table $\mathbf{1 .}$ According to the 2-level four variables concept, a complete matrix would have been based on $24=16$ runs, and 6 runs were center point runs for statistical reasons. Thus, a factorial matrix of 22 runs was used. Each variable was investigated at high (+1) and low (-1) levels. Runs of the center point were included in the matrix and statistical analysis was used to identify the effect of each variable on hydrogen production. The runs were randomized for statistical reasons. The significances of the variables were identified on the basis of confidence levels above 95\% ( $\mathrm{P}<0.05)$. Table 2 shows the design matrix with a hydrogen production potential and rate of hydrogen production as a response.

\section{b) Central Composite Design (CCD)}

The Response surface methodology (RSM), a mathematical and statistical technique for building models, evaluating relative significance of several independent variables (i.e., environmental factors), and for determining optimum conditions for desirable responses [4] was employed in this study. CCD is a widely used experimental RSM in order to estimate a second-order polynomial approximation (quad-

Table 1. Variables in Actual Values, for Screening by the 2-Level Factorial Design

\begin{tabular}{|c|c|c|c|c|}
\hline & Variable & Unit & Low Level & High Level \\
\cline { 3 - 5 } & & & $\mathbf{( - 1 )}$ & 5 \\
\hline \hline A & $\mathrm{pH}$ & ${ }^{\circ} \mathrm{C}$ & 70 & 100 \\
\hline B & Heat treatment & $\%$ & 10 & 20 \\
\hline C & Inoculum size & $\mathrm{g} / \mathrm{L}$ & 40 & 80 \\
\hline D & Substrate concentration & & \multirow{2}{*}{6} \\
\hline
\end{tabular}


Table 2. Two-Level Factorial Design of Variables (in Coded Levels) with $\mathbf{P}$ and $\mathbf{R}_{\mathrm{m}}$ as the Response

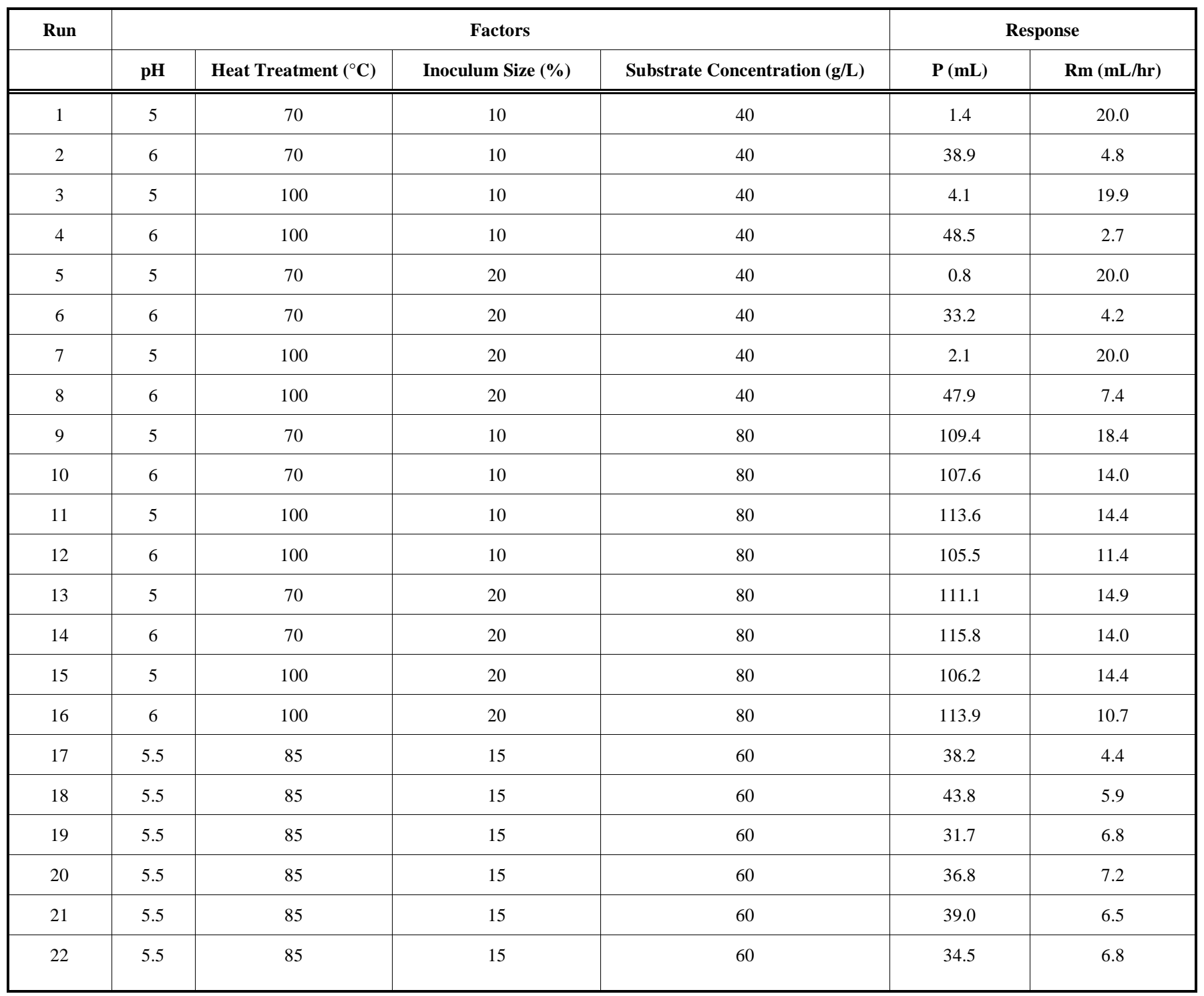

ratic) to a response in that region [15]. In each case, the matrix incorporated five central points and 2 axial points (with one variable set at extreme \pm 1 level and the other variable at central point level). Table $\mathbf{3}$ shows the actual and the coded levels of the variables tested for each isolate. The coding of the variables was done following the equation:

$x_{i}=\frac{X_{i}-X_{i}^{*}}{\Delta X_{i}}$

where $x_{i}$ is the coded value of the ${ }_{i}$ th test variable, $X_{i}$ an uncoded value of the ${ }_{i}$ th test variable, $X_{i}^{*}$ the value of $X_{i}$ at the center point of the investigated area, and $\Delta X_{i}$ is the step size.
$Y=A_{o}+\sum_{i=1}^{k} A_{i} X_{i}+\sum_{i=1}^{k} A_{i i} X_{i}^{2}+\sum_{i=1}^{k} \sum_{j=1}^{k} A_{i j} X_{i} X_{j}$

The response variable $\left(P_{\mathrm{s}}\right.$ and $\left.R_{\max }\right)$ was fitted using a predictive polynomial quadratic equation in order to correlate the response variable to the independent variables. The general form of the predictive polynomial quadratic equation is where $x i$ are the input variables, which influence the response variable $Y, A_{0}$ the offset term, $A_{i}$ the ${ }_{i}$ th linear coefficient, $A_{i i}$ the quadratic coefficient and $A_{i j}$ is the ${ }_{i j}$ th interaction coefficient. As Eq. (3) is determined, it can be used to locate the optimum for the set of independent variables by the partial derivatives of the model response with respect to

Table 3. Coded and Actual Values of Variables Selected for CCD

\begin{tabular}{|c|c|c|c|c|c|c|}
\hline Variable & Unit & $\mathbf{- 2}$ & $\mathbf{- 1}$ & $\mathbf{0}$ & $\mathbf{1}$ \\
\hline \hline $\mathrm{A} \mathrm{pH}$ & & 4.5 & 5 & 5.5 & 6 & 6.5 \\
\hline B substrate concentration & $\mathrm{g} / \mathrm{L}$ & 20 & 40 & 60 & 80 \\
\hline
\end{tabular}


the individual independent variables is equal to zero. In general, the model was considered to be efficient and workable if it had a significant $F$-value, and insignificant lack-of-fit $F$ value and a good $\mathrm{R}^{2}$ (multiple correlation coefficient).

The conditions that could give maximum hydrogen production were predicted using the numerical optimization in Design-Expert 7.0 (Stat Ease Inc.). Only the factors considered in model building were varied for prediction, other insignificant variables were maintained at constant values (' 0 ' coded level) as in the 2-level factorial design.

\section{RESULTS AND DISCUSSION}

\section{Preliminary Investigation on Biohydrogen Production by the 2-Level Factorial Design}

Four variables which affect biohydrogen production were selected for the 2-level factorial design (Table 1). The effects of the selected variables on biohydrogen production were evaluated in 22 experiments including 6 center points. Table 2 shows the responses obtained in terms of hydrogen production potential $\left(\mathrm{P}_{\mathrm{s}}\right)$ determined by modified Gompertz equation. The responses obtained were statistically evaluated and the variables with confidence levels above $95 \%$ gave significant effect on hydrogen production.

$\mathrm{pH}(\mathrm{P}<0.0001)$ showed a significant effect on both responses, biohydrogen production and hydrogen production rate. Besides $\mathrm{pH}$, substrate concentration $(\mathrm{P}<0.0001, \mathrm{P}=$ 0.0383 ) was the most significant variable affecting both responses. Thus, the variables that significantly affected hydrogen production could be identified by using the 2-level factorial design.

Table 2 shows the maximum hydrogen production potential and hydrogen production rate were $116 \mathrm{~mL}$ and 20
$\mathrm{mL} / \mathrm{hr}$, respectively. The model for the hydrogen production potential was highly significant $(\mathrm{P}<0.0001)$, while the lackof-fit was not significant $(\mathrm{P}>0.05)$ according to the analysis of variance (data not shown). The coefficient of determination $\left(\mathrm{R}^{2}\right)$ was 0.9897 , which explained $98 \%$ variability of the response variable.

\section{Central Composite Design}

Based on the identification of variables by the 2-level factorial design, a central composite design was developed for variables that significantly affected hydrogen production. All the non-significant factors were maintained at central points (' 0 ' coded level) of the levels used in the 2-level factorial design. Table $\mathbf{3}$ shows the coded and real values of the levels of variables selected in CCD. The design matrix of the variables together with the experimental results is shown in Table 4.

The significance test on the regression model and individual model coefficients were performed by using ANOVA. The backward elimination procedure was been chosen to manually select the appropriate model coefficient by reducing the insignificant terms for the specific hydrogen production potential $\left(\mathrm{P}_{\mathrm{s}}\right)$ response. The significant model and the corresponding significant model terms are tabulated in Table 5. The regression model and terms were considered to be significant when the "Prob $>F$ " was less than 0.05.

\section{Effects of $\mathrm{pH}$ and Substrate Concentration on Hydrogen Yield}

By applying multiple regression analysis on the experimental data, the following second-order polynomial equation was used to explain the hydrogen production:

Table 4. Central Composite Design of Variables for $P_{s}$ and $R_{m}$

\begin{tabular}{|c|c|c|c|c|}
\hline Run & Factor 1 & Factor 2 & Response $1^{\text {a }}$ & Response 2 \\
\hline $1^{\mathrm{b}}$ & 5 & 40 & 26.25 & 43.43 \\
\hline $2^{\mathrm{b}}$ & 6 & 40 & 72.15 & 60.77 \\
\hline $3^{\mathrm{b}}$ & 5 & 80 & 203.09 & 52.19 \\
\hline $5^{\mathrm{b}}$ & 4.5 & 60 & 25.49 & 12.74 \\
\hline $6^{\mathrm{b}}$ & 6.5 & 60 & 164.56 & 36.30 \\
\hline $7^{\mathrm{b}}$ & 5.5 & 20 & 85.04 & 92.54 \\
\hline $8^{\mathrm{b}}$ & 5.5 & 100 & 312.75 & 144.27 \\
\hline 12 & 5.5 & 60 & 223.67 & 67.91 \\
\hline 13 & 5.5 & 60 & 223.81 & 71.85 \\
\hline 14 & 5.5 & 60 & 203.32 & 65.09 \\
\hline
\end{tabular}

${ }^{\mathrm{a}}$ Response in terms of hydrogen production potential in $\mathrm{mL} \mathrm{H}_{2} / \mathrm{g}$ carbohydrate.

${ }^{\mathrm{b}}$ The trials were replicated three times. 
Table 5. Analysis of Variance for the Regression Model and the Respective Model Terms (Original and Adjusted ANOVA) for $P_{s}$

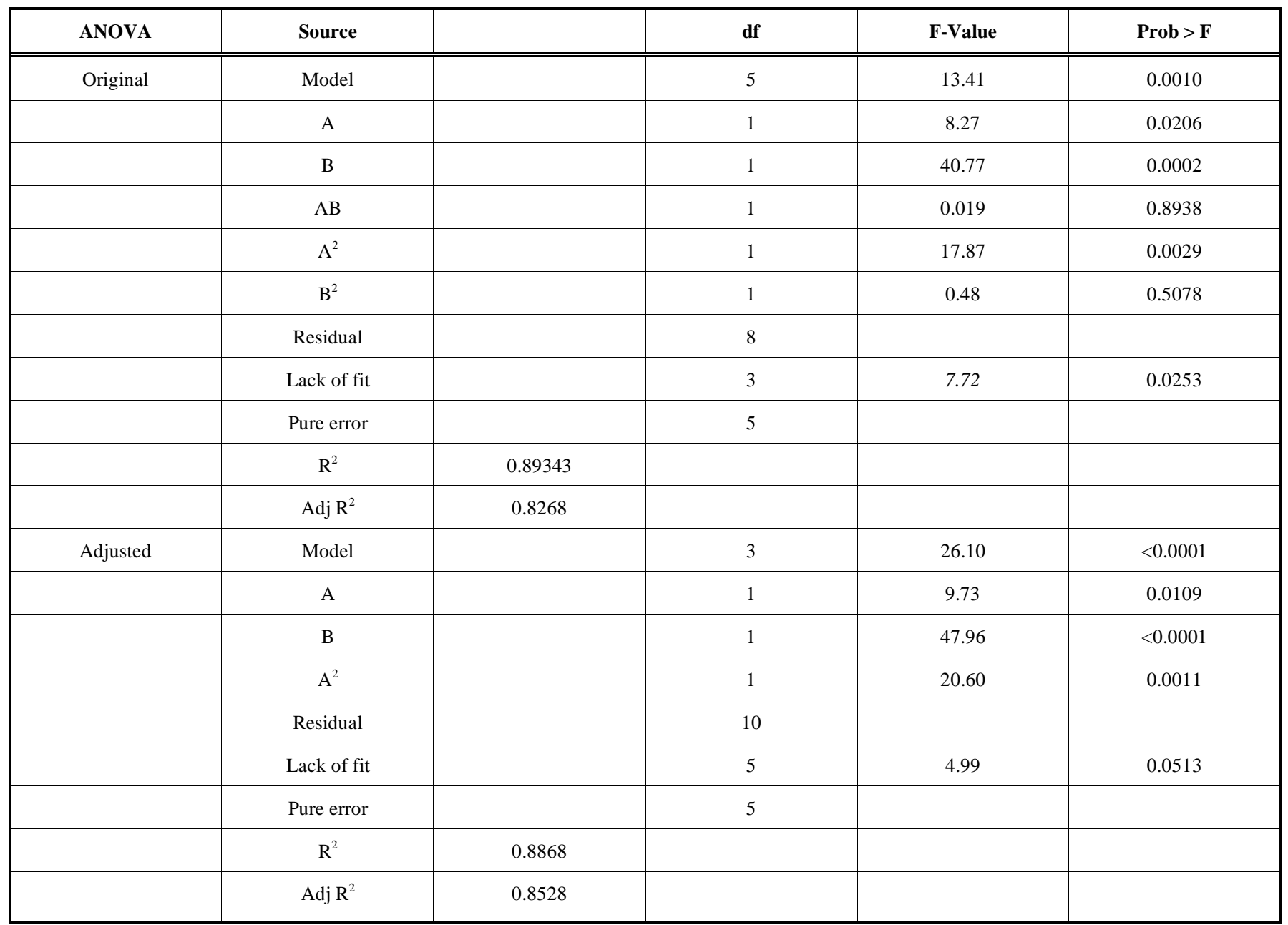

$P_{s}=203.28+30.00 A+66.59 B-31.09 A_{1}^{2}-5.09 B^{2}-2.49 A B$

where, $\mathrm{P}_{\mathrm{s}}$ is the predicted hydrogen production potential; A and $\mathrm{B}$ are the coded values of $\mathrm{pH}$ and substrate concentration, respectively.

Analysis of variance (ANOVA) of the backward elimination model (Table 5) showed that the model was highly significant $(\mathrm{P}<0.0001)$, while the lack-of-fit was not significant $(\mathrm{P}>0.05)$. The high value of the regression coefficient $\left(\mathrm{R}^{2}=0.8868\right)$ could explain $89 \%$ of the variability of the response variable suggesting that the model was an accurate representation of the data. Eq. (5) could appropriately describe the effects of $\mathrm{pH}$ and substrate concentration on the hydrogen yield obtained in this study. ANOVA of the adjusted model (Table 5) also showed that the linear effects of $\mathrm{pH}$ (A), substrate concentration (B) and quadratic effect of $\mathrm{pH}\left(\mathrm{A}^{2}\right)$ were the significant terms for hydrogen production, which means these terms had great impacts on hydrogen yield [20].

Stoichiometrically, each gram of carbohydrate produced a maximum of $553 \mathrm{~mL} \mathrm{H}_{2}$ assuming acetic acid as the byproduct. The maximum yield of $312 \mathrm{~mL} \mathrm{H}_{2} / \mathrm{g}$ carbohydrate was obtained represented $56.4 \%$ of the theoretical yield. This value was lower than that expected in theory because the characteristics of palm oil waste varied from those of the synthetic waste. Subsequently, the maximum hydrogen yield of $272 \mathrm{~mL} \mathrm{H}_{2} / \mathrm{g}$ carbohydrate was estimated from Eq. (5) at pH 5.75 and substrate concentration of $80 \mathrm{~g} / \mathrm{L}$ (Table 7).

Fig. (1) shows the response surface plot (a) and the corresponding contour plot (b) based on Eq. (5). As is shown in the figure, initial $\mathrm{pH}$ and substrate concentration were maintained at 5.75 and $80 \mathrm{~g} / \mathrm{L}$, respectively. The contour of $\mathrm{P}_{\mathrm{s}}$ with respect to $\mathrm{pH}$ and substrate showed an elongated shaped running diagonally on the plot, suggesting that both factors were interdependent, or there was a significant interaction on $\mathrm{P}_{\mathrm{s}}$ between $\mathrm{pH}$ and substrate concentration [4].

\section{Effects of pH and Substrate Concentration on Hydrogen Production Rate}

In a similar way, response surface analysis was performed for evaluating the effect of $\mathrm{pH}$ and substrate concentration on $\mathrm{R}_{\mathrm{m}}$. The quadratic model was constructed as follow:

$R_{m}=62.32+9.72 A+12.98 B+8.70 A B-9.62 A^{2}+13.85 B^{2}$

ANOVA of the model (Table 6) showed that the model was highly significant $(\mathrm{P}<0.0001)$, while the lack-of-fit was not significant $(\mathrm{P}>0.05)$. The model was accurate based on 
a

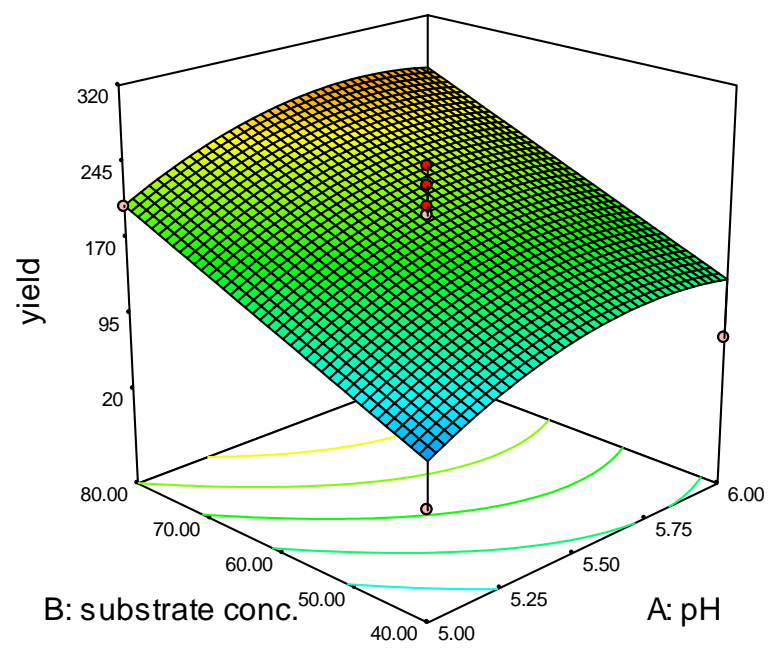

b

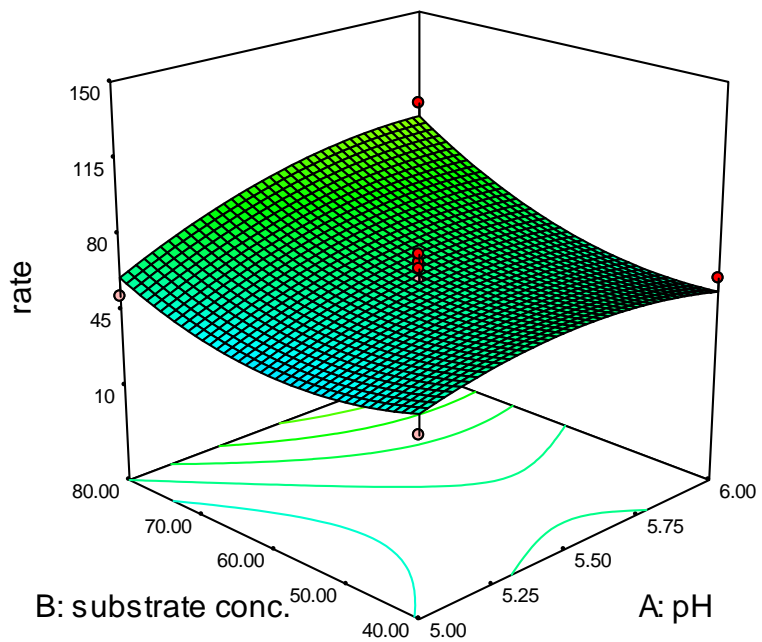

Fig. (1). Response surface plot and corresponding contour plot for $\mathrm{P}_{\mathrm{s}}(\mathbf{a})$ and $\mathrm{R}_{\mathrm{m}}(\mathbf{b})$.

Table 6. Analysis of Variance for the Regression Model and the Respective Model Terms for $R_{m}$

\begin{tabular}{|c|c|c|c|c|c|}
\hline ANOVA & Source & & df & F-value & Prob $>$ F \\
\hline \multirow{7}{*}{ Original } & A & & 1 & 10.63 & 0.0115 \\
\hline & B & & 1 & 18.97 & 0.0024 \\
\hline & $\mathrm{AB}$ & & 1 & 2.84 & 0.1305 \\
\hline & $\mathrm{B}^{2}$ & & 1 & 43.51 & 0.0002 \\
\hline & Residual & & 8 & & \\
\hline & Lack of fit & & 3 & 1.23 & 0.3909 \\
\hline & Pure error & & 5 & & \\
\hline
\end{tabular}

the high value of the regression coefficient $\left(R^{2}=0.9359\right)$, indicating $94 \%$ variability of the response variable. Eq. (6) could describe the effect of $\mathrm{pH}$ and substrate concentration on hydrogen production rate very well.

Apart from that, ANOVA analysis (Table 6) also showed the significant terms for $\mathrm{R}_{\mathrm{m}}$ which comprised the secondorder effect of $\mathrm{pH}\left(\mathrm{A}^{2}\right)$ and the second-order effect of substrate concentration $\left(B_{2}\right)$. Independent factors, main effects of $\mathrm{pH}$ (A) and substrate concentration (B) did exert significant effects on the $R_{m}$ in the system. These indicated that these factors had great impacts on the hydrogen production rate. However, the interactive effects of $\mathrm{pH}$ and substrate concentration $(\mathrm{AB})$ were not significant on the hydrogen production rate thus indicating that this term had little impact on the hydrogen production rate.

The optimum conditions for $\mathrm{R}_{\mathrm{m}}$ were found to be $\mathrm{pH} 5.98$ and substrate concentration of $80 \mathrm{~g} / \mathrm{L}$ after setting the partial derivatives of Eq. (6) to zero with respect to the corresponding variables. The maximum response value for $R_{m}$ was estimated as $98 \mathrm{~mL} / \mathrm{h}$ (Table 7). The contour was plotted based on Eq. (6) (Fig. 1b). As is shown in Fig. (1b), the $\mathrm{R}_{\mathrm{m}}$ significantly presented as a "saddle" [8]. The $\mathrm{R}_{\mathrm{m}}$ increased from 70 to $88 \mathrm{~mL} / \mathrm{h}$ while the $\mathrm{pH}$ level and substrate concentration increased from 5.5 to 6.0 and 60 to $80 \mathrm{~g} / \mathrm{L}$, respectively. It is evident that the hydrogen production rate reached maximum as the substrate concentration increased from $60 \mathrm{~g} / \mathrm{L}$ to 80 $\mathrm{g} / \mathrm{L}$ in the $\mathrm{pH}$ range of 5.5-6.0. Controlled $\mathrm{pH}$ could stimulate microorganisms to produce hydrogen and the system would achieve a maximum hydrogen production potential [8].

Table 7 shows the $\mathrm{pH}$ varied for the optimum conditions of $P_{s}$ and $R_{m}$. A higher $p H$ was likely more favorable for $R_{m}$ compared to $\mathrm{P}_{\mathrm{s}}$. However, substrate concentration had a similar influence on $\mathrm{P}_{\mathrm{s}}$ and $\mathrm{R}_{\mathrm{m}}$ resulting in identical optimum substrate concentration values for both of them [4]. To opti- 
Table 7. Measured and Calculated Values of the Confirmation Experiments

\begin{tabular}{|c|c|c|}
\hline Optimum Conditions & Maximum Calculated Value & Experimental Value \\
\hline \hline $\begin{array}{c}\mathrm{pH}=5.75 \\
\text { substrate }=80 \mathrm{~g} / \mathrm{L}\end{array}$ & $\mathrm{P}_{\mathrm{s}}=272^{\mathrm{a}}$ & $\mathrm{P}_{\mathrm{s}}=226^{\mathrm{a}}(23)$ \\
\hline $\begin{array}{c}\mathrm{pH}=5.98 \\
\text { substrate }=80 \mathrm{~g} / \mathrm{L}\end{array}$ & $\mathrm{R}_{\mathrm{m}}=98^{\mathrm{b}}$ & $\mathrm{R}_{\mathrm{m}}=72^{\mathrm{b}}(13)$ \\
\hline
\end{tabular}

${ }^{\mathrm{a}}$ Response in terms of hydrogen production potential ( $\mathrm{mL} \mathrm{H}_{2} / \mathrm{g}$ carbohydrate).

${ }^{b}$ Response in terms of hydrogen production rate $\left(\mathrm{mL} \mathrm{H}_{2} / \mathrm{hr}\right)$.

mize $P_{s}$ and $R_{m}$, an overlay contour plot was developed (Fig. 2). Based on the overlay plot, the optimal conditions were found to be at $\mathrm{pH}$ range from 5.4 to 6.0, while the substrate concentration was $80 \mathrm{~g} / \mathrm{L}$.

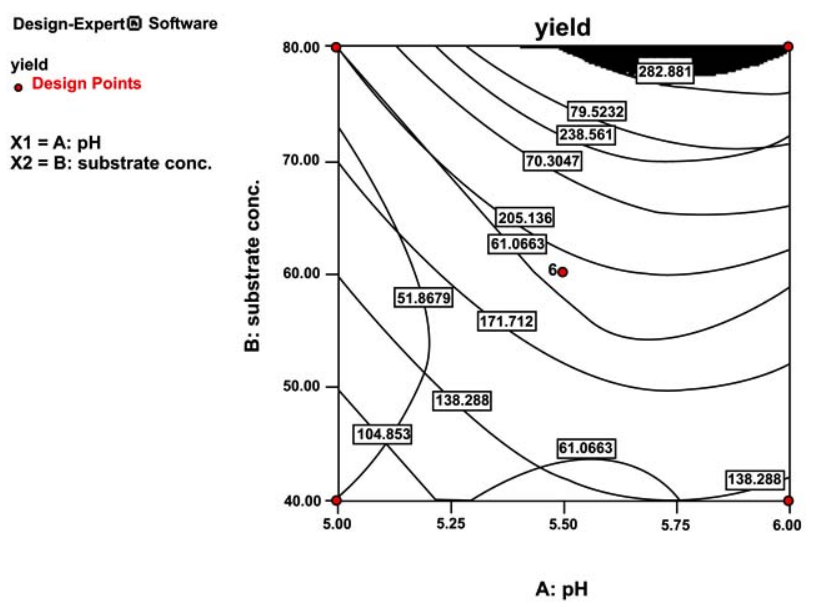

Fig. (2). The overlay plot of both contour for $P_{s}$ and $R_{m}$.

To indicate the accurate optimum point from the overlay plot, the independent factors and all the responses that were considered to be important were optimized simultaneously using the numerical optimization method in the Design Expert Software [19]. From the analysis, the highest efficiency of hydrogen production occurred at $\mathrm{pH} 5.86$ and substrate concentration of $80 \mathrm{~g} / \mathrm{L}$ which confirmed that the area for the optimum point was true.

\section{Validation of the Identified Optimal Conditions}

Two additional confirmation experiments were conducted for the validity of the statistical experimental strategies and to gain a better understanding of biohydrogen production from mixed cultures. The chosen conditions for $\mathrm{pH}$ and substrate concentration, and the experimental results are listed in Table 7. The results obtained revealed that the optimum $P_{s}$ and $R_{m}$ measured were close to those estimated using RSM and this confirmed that the RSM analysis was a useful technique for optimizing the fermentative biohydrogen production processes [4].

Many researchers have reported the optimization of the fermentative hydrogen production process using the response surface methodology $[4,8,11]$. Table $\mathbf{8}$ summarizes the optimal temperatures, $\mathrm{pH}$ and substrate concentration obtained in this study in comparison to those obtained by previous researchers. Since the experimental conditions and response variable in this study and those of the other studies differed, the optimal (initial) $\mathrm{pH}$ and substrate concentration for biohydrogen production varied. However, most of the optimal temperatures were in the mesophilic range $\left(35-40{ }^{\circ} \mathrm{C}\right)$.

The optimal substrate concentration obtained in this study was $80 \mathrm{~g} / \mathrm{L}$ POME, while the optimal substrate concentration obtained by Atif et al. [20] was 70 g/L POME. The difference of the hydrogen yield obtained in this study and that of Atif et al. [20] was because of the different temperatures used during the fermentative hydrogen production. The optimal substrate concentrations obtained by $\mathrm{Mu}$ et al. [4] were about $25 \mathrm{~g} / \mathrm{L}$ sucrose. The optimal initial $\mathrm{pH}$ ob-

Table 8. Comparison of the Optimal Conditions for Biohydrogen Production Obtained in this Study and those of other Studies Using Mixed Culture

\begin{tabular}{|c|c|c|c|c|}
\hline $\mathbf{p H}$ & Temperature $\left({ }^{\circ} \mathbf{C}\right)$ & Substrate & $\begin{array}{c}\mathbf{H}_{2} \text { Yield } \\
\left(\mathbf{m L} \mathbf{H}_{2} / \mathbf{g} \text { Carbohydrate) }\right.\end{array}$ & Reference \\
\hline \hline 5.5 & 34.8 & Sucrose & 90 & 252 \\
\hline 5.4 & 37 & Sucrose & 346 & 92 \\
\hline 4.5 & 37 & Rice slurry & Starch & $21]$ \\
\hline $6 . *^{*}$ & 55 & POME & $226^{\mathrm{b}}$ & {$[22]$} \\
\hline $5.75^{*}$ & 37 & & This study \\
\hline
\end{tabular}

*initial $\mathrm{pH}$. 
tained in this study was 5.75 , while the optimal initial $\mathrm{pH}$ obtained by Fan et al. [8] was 5.40.

\section{CONCLUSION}

The initial $\mathrm{pH}$ and substrate concentration had impacts on fermentative biohydrogen production from POME individually and interactively. The maximum hydrogen yield of 272 $\mathrm{mL} \mathrm{H}_{2} / \mathrm{g}$ carbohydrate was estimated at initial $\mathrm{pH} 5.75$ and substrate concentration of $80 \mathrm{~g} / \mathrm{L}$. The maximum hydrogen production rate of $98 \mathrm{~mL} / \mathrm{hr}$ was estimated at initial $\mathrm{pH} 5.98$ and substrate concentration of $80 \mathrm{~g} / \mathrm{L}$. This showed that RSM is a useful tool to estimate the maximum value of biohydrogen production since it was successfully used to find the influences and interactions of the variables on the specific hydrogen production potential (yield) and the specific hydrogen production rate.

\section{ABBREVIATIONS}

$$
\begin{array}{ll}
\mathrm{CCD} & =\text { Central composite design } \\
\mathrm{COD} & =\text { Chemical oxygen demand } \\
\mathrm{GC} & =\text { Gas chromathograph } \\
\mathrm{FD} & =\text { Factorial design } \\
\mathrm{POME} & =\text { Palm oil mill effluent } \\
\mathrm{P}_{\mathrm{S}} & =\text { Specific hydrogen production } \\
\mathrm{R}_{\mathrm{m}} & =\text { Hydrogen production rate } \\
\mathrm{RSM} & =\text { Response surface methodology }
\end{array}
$$

\section{ACKNOWLEDGEMENTS}

The authors would like to thank the National Science Fund and the Ministry of Science, Technology and Innovation (MOSTI) for financial support throughout this study.

\section{REFERENCES}

[1] O-Thong S, Prasertsan $\mathrm{P}$, Intrasungkha $\mathrm{N}$, Dhamwichukorn $\mathrm{S}$, Birkeland NK. Optimization of simultaneous thermophilic fermentative hydrogen production and COD reduction from palm oil mill effluent by Thermoanaerobacterium-rich sludge. Int J Hydrogen Energy 2008; 33: 1221-31.

[2] Karlsson A, Vallin L, Ejlertsson J. Effects of temperature, hydraulic retention time and hydrogen extraction rate on hydrogen production from the fermentation of food industry residues and manure. Int J Hydrogen Energy 2008; 33: 953-62.

[3] Kyazze G, Dinsdale R, Hawkes FR, Guwy AJ, Premier GC, Donnison IS. Direct fermentation of fodder maize, chicory fructants and perennial ryegrass to hydrogen using mixed microflora. Biores Tech 2008; 99: 8833-39.

[4] Mu Y, Wang G, Yu HQ. Response surface methodological analysis on biohydrogen production by enriched anaerobic cultures. Enzyme Microb Tech 2006; 38: 905-13.
[5] Zhang Y, Yan L, Chi L, Long X, Mei Z, Zhang Z. Start-up and operation of anaerobic EGSB reactor treating palm oil mill effluent. Int J Hydrogen Energy 2008; 20: 658-63.

[6] O-Thong S, Prasertsan P, Intrasungkha N, Dhamwichukorn S, Birkeland NK. Improvement of biohydrogen production and treatment efficiency on palm oil mill effluent with nutrient supplementation at thermophilic condition using an anaerobic sequencing batch reactor. Enzyme Microb Tech 2007; 41: 583-90.

[7] Pan CM, Fan YT, Xing Y, Hou HW, Zhang ML. Statistical optimization of process parameters on biohydrogen production from glucose by Clostridium sp. Fanp2. Biores Tech 2008; 99: 3146-54.

[8] Fan YT, Li CL, Lay JJ, Hou HW, Zhang GS. Optimization of initial substrate and $\mathrm{pH}$ levels for germination of sporing hydrogenproducing anaerobes in cow dung compost. Biores Technol 2004; 91: 189-93.

[9] Lay JJ, Lee YJ, Noike T. Feasibility of biological hydrogen production from organic fraction of municipal solid waste. Water Res 1999; 33 (11): 2579-86.

[10] Chong M-L, Rahim RA, Shirai Y, Hassan MA. Biohydrogen production by Clostridium butyricum EB6 from palm oil mill effluent. Int J Hydrogen Energy 2009; 34: 764-71.

[11] Van Ginkel S, Sung S, Lay JJ. Biohydrogen production as a function of pH and substrate concentration. Environ Sci Tech 2001; 35: 4726-30.

[12] Hawkes FR, Hussy I, Kyazze G, Dinsdale R, Hawkes DL. Continuous dark fermentative hydrogen production by mesophilic microflora: Principles and progress. Int J Hydrogen Energy 2007; 32: 172-84.

[13] Lin CY, Chang CC, Hung CH. Fermentative hydrogen production from starch using natural mixed cultures. Int J Hydrogen Energy 2008; 33: 2445-53.

[14] Ruggeri B, Tommasi T, Sassi G. Experimental kinetics and dynamics of hydrogen production on glucose by hydrogen forming bacteria (HFB) culture. Int J Hydrogen Energy 2009; 34: 753-63.

[15] Wang J, Wan W. Optimization of fermentative hydrogen production process by response surface methodology. Int J Hydrogen Energy 2008; 33: 6976-84.

[16] Venkata MS, Vijaya BY, Murali KP, Chandrasekhara RN, Lalit $\mathrm{BV}$, Sharma PN. Biohydrogen production from chemical wastewater as substrate by selectively enriched anaerobic mixed consortia: Influence of fermentation $\mathrm{pH}$ and substrate concentration. Int $\mathrm{J} \mathrm{Hy}-$ drogen Energy 2007; 32: 2286-95.

[17] American Public Health Association, Standard methods for examination of water and wastewater $19^{\text {th }}$ ed. USA: Washington DC 1998; p. 1220.

[18] Rodrigues L, Teixeira J, Oliveira R, Henny CM. Response surface optimization of the medium components for the production of biosurfactants by probiotic bacteria. Process Biochem 2006; 41: 1-10.

[19] Sim JH, Azlina HK, Wei SL, Ghasem N. Clostridium aceticum - A potential in catalizing carbon monoxide to acetic acid: application of response surface methodology. Enzyme Microb Tech 2007; 40: 1234-43.

[20] Atif AAY, Fakhru'l-Razi A, Ngan MA, Morimoto M, Iyuke SE, Veziroglu NT. Fed batch production of hydrogen from palm oil mill effluent using anaerobic microflora. Int $\mathbf{J}$ Hydrogen Energy 2005; 30(2): 1393-97.

[21] Fang HHP, Li C, Zhang T. Acidophilic biohydrogen production from rice slurry. Int J Hydrogen Energy 2006; 31: 683-92.

[22] Zhang T, Liu H, Fang HHP. Biohydrogen production from starch in wastewater under thermophilic condition. Environ Manage 2003; 69: $149-56$.

(C) Rasdi et al.; Licensee Bentham Open.

This is an open access article licensed under the terms of the Creative Commons Attribution Non-Commercial License (http://creativecommons.org/licenses/by-nc/3.0/) which permits unrestricted, non-commercial use, distribution and reproduction in any medium, provided the work is properly cited. 